\title{
PROSTATE SPECIFIC ANTIGEN DYNAMICS AND FEATURES IN PROSTATE CANCER
}

\author{
Kristofs Folkmanis ${ }^{1,5, \#}$, Amrou Hajjar ${ }^{2}$, Elizabete Junk ${ }^{1,2}$, Evelīna Merdane ${ }^{1}$, \\ Valdis Folkmanis ${ }^{1}$, Inese Folkmane ${ }^{1,4}$, and Sergejs Isajevs ${ }^{1,3}$ \\ 1 Faculty of Medicine, University of Latvia, 3 Jelgavas Str., LV-1004, Rīga, LATVIA \\ 2 St. Bonifatius Hospital, Lingen (Ems), 13 Wilhelm Str., Lingen (Ems), 49808, GERMANY \\ ${ }^{3}$ Rīga East University Hospital, 2 Hipokrāta Str., Rīga, LV-1038, LATVIA \\ ${ }^{4}$ Pauls Stradiṇš Clinical University Hospital, Rīga, 13 Pilsoṇu Str., LV-1002, LATVIA \\ ${ }^{5}$ Elbe Hospital in Stade, Hamburg-Eppendorf University Hospital, Bremervoerder Str. 111, 21682, Stade, GERMANY \\ Corresponding author, kristofs87@inbox.lv
}

Communicated by Ingrīda Rumba-Rozenfelde

\begin{abstract}
Despite the common use of the prostate-specific antigen (PSA) serum level as a tumour marker in diagnosis of prostate cancer, it seems that the PSA doubling time (PSADT) and PSA velocity (PSAV) could be more useful indicators of tumour behaviour and prognosis for patients. The aim of the study was to evaluate the value of PSAV and PSADT in the diagnosis of prostate cancer and their relationship with prostate cancer histopathological characteristics. Eighty-six patients undergoing radical prostatectomy were enrolled in the study. Based on the PSA measurements the PSA dynamic values were calculated: PSADT and PSAV. In addition, clinical and histopathological characteristics, including disease stage and prognostic groups were evaluated. The obtained results showed that the first PSA value was $4.29 \mathrm{ng} / \mathrm{ml}(1.28-13.56)$, the second PSA value was $7.76 \mathrm{ng} / \mathrm{ml}(7.60-47.60)$, and the third PSA value was $9.67 \mathrm{ng} / \mathrm{ml}(2.56-98.50)$. The median PSADT was 51.01 months (7.80-311.81) and the median PSAV was $2.66 \mathrm{ng} / \mathrm{ml} / \mathrm{per}$ year (0.22-4.66). In addition, significant correlations between PSAV and pre- and post-operative Gleason score, and prognostic groups were observed. Significant correlation between PSADT and pre- and pos-toperative Gleason score and prognostic risk groups was demonstrated. This study demonstrated that PSAV and PSADT were significantly correlated with postoperative Gleason score and prognostic risk groups, demonstrating its role in the diagnosis of prostate cancer progression.
\end{abstract}

Keywords: prostate cancer, PSA-doubling time (PSADT), PSA-velocity (PSAV), risk stratification.

\section{INTRODUCTION}

Prostate cancer (PCa) is recognised as one of the most important medical problems affecting the male population. In Europe, $\mathrm{PCa}$ is one of the most common neoplastic forms with an approximate incidence of 214 cases per 1000 men, dividing the frontrunner position with lung and colorectal cancer. PCa is currently the second most common cause of cancer death in men (Post et al., 1999; Bartsch et al., 2001; Lu-Yao et al., 2002; Thompson et al., 2004; Ilic et al., 2007; Mottet et al., 2020; Folkmanis et al., 2021).

Prostate-specific antigen (PSA) is a kallikrein-like serine protease produced almost exclusively by prostate epithelial cells. Measurement of (PSA) ushered in a new era in PCa diagnostics. However, its standardised measurement did not confirm its value to be considered a screening method. Therefore, in the diagnosis of $\mathrm{PCa}$, there is still a need for a universal, inexpensive, easy-to-use non-invasive screening method that could diagnose $\mathrm{PCa}$ and provide information on its development potential (Post et al., 1999; Bartsch et al., 2001; Lu-Yao et al., 2002; Thompson et al., 2004; Ilic et al., 2007; Mottet et al., 2020; Folkmanis et al., 2021).

The following methods could be considered as dynamic PSA parameters: PSA velocity (PSAV), defined as the absolute increase in serum PSA value (ng/ml/year) during a year (Carter et al., 1992); and PSADT, which measures the 
increase in serum PSA per unit time, reflecting its relative variability (Schmid et al., 1993).

PSAV is the rate of change in PSA values with repeated measurement over time. Accurate use of PSAV for early detection of prostate cancer requires the use of two or more PSA levels collected over approximately 1.0 to 2 years (Carter et al., 1992; Schmid et al., 1993).

Previous findings demonstrated that PSAV provides significant predictive information for estimating prostate cancer risk. Modest increases in PSA are associated with increased risk of cancer, whereas more dramatic PSA rises are associated with a diminishing risk of cancer and higher rate of inflammation (Arlen et al., 2008; Heidenreich, 2008).

PSADT is an important value that potentially predicts metastatic disease progression (Heidenreich, 2008).

It has been previously demonstrated that the rate of enhancement of serum PSA was associated with disease stage and the Gleason score (Heidenreich, 2008; Ramirez et al., 2008).

Post-treatment PSAV is primarily used to help predict PCa aggressiveness, while post-treatment PSADT is primarily used to determine the biochemical recurrence survival of men with PCa (Schmid et al., 1993).

Information available in the literature on the use of PSA dynamic values before RP in assessing tumour development is controversial, as there are reports that pre-treatment PSAV is a sensitive specific early clinical marker of PCa development (Carter et al., 1992) and that PSADT is more specific for patients with a higher tumour stage and grade (Schmid et al., 1993).

There are also studies demonstrating that PSADT and PSAV do not provide additional information compared to the information provided by PSA alone (Billis et al., 2008; Heidenreich, 2008; Ramirez et al., 2008). In addition no correlation has been determined between PSAV and PSADT, and the clinical and histological stage of PCa (O'Brien et al., 2009). These contradictory results suggested that the cutoff of PSADT may vary, depending on different populations and end-points.

The aim of our study was to analyse the value of PSA, PSAV, and PSADT in the diagnosis of prostate cancer and their correlation with histopathological characteristics in a single Urology unit in Pauls Stradin̄š Clinical University Hospital in Latvia.

\section{PATIENTS AND METHODS}

Patients. Eighty-six patients with prostate cancer undergoing radical prostatectomy between 27 April 2011 and 15 December 2011 were retrospectively enrolled in the study. The median age of patients was 62.9 years $(\mathrm{SD} \pm 5.56$; 50.0-75.0). The data used in the study were obtained from the Department of Urology of Pauls Stradiņš Clinical Uni- versity Hospital and from the database of Pauls Stradin̄š Clinical University Hospital Outpatient Department.

The inclusion criteria were the following: patient age more than 18 years, with histopathologically proved prostate acinar adenocarcinoma and all available clinical data, including three PSA measurements, as well as follow-up data.

Exclusion criteria were patient age less than 18 years, patients with synchronous malignancies, patients who received previous neoadjuvant treatment, and patients with histopathological cancer type other that acinar adenocarcinoma.

The study protocol was approved by the Ethical Committee of the Institute of Carciology and Regenerative Medicine, University of Latvia (No. 67/2012; from 12.10.2012).

The study was in accordance with the declaration of Helsinki and Oviedo Convention. All patients signed and informed consent to participate in the study.

The study cohort included participants from the Department of Urology, Pauls Stradņš Clinical University Hospital, Rīga, Latvia.

Methods. The clinical, biochemical and histopathological data were retrospectively analysed, including the age of patients (years), date of admission to the hospital, check-out date, date of surgical treatment, PSA values (preoperative PSA, first, second and third measurement), the number of preoperative biopsy samples in which adenocarcinoma tissues had been detected and prostate size by US testing.

The clinical stage of the tumour before the surgery was assessed according TNM staging. After radical prostatectomy, the histopathological characteristics of the tumour such as tumour type, Gleason grade, and Grade group were analysed. The staging was performed according to the AJCC (The American Joint Committee on Cancer) 8th edition Guidelines.

The PSA dynamic values PSADT, PSAV were calculated based on three PSA measurements using PSA dynamic value calculator (http://nomograms.mskcc.org; Pound et al., 1999).

Prognostic groups were stratified to low and high risks according to clinical and histological stages of pre- and postoperative tumours and PSA values, based on classification by Heidenreich (2008).

Correlation was assessed between PSA, PSA dynamic values, prognostic groups and prostate size, positive cancer core biopsy samples, Gleason score, qand Grade groups.

The results were analysed using the Student's t test, Chi square test, and ANOVA for statistical evaluation of differences. The Spearman's test was used to determine correlation. The results were considered statistically significant if $p<0.05$. 
The data were collected electronically and analysed using the statistical data processing software SPSS version 20.

\section{RESULTS}

The second and third PSA values significantly differed from the first PSA value $(p<0.05$, Table 1$)$.

The mean number of positive tumour biopsy samples was 2.0 (1.00-8.00). Most patients (21 patients, 24.42\%) had one positive tumour biopsy of eight, and only two patients $(2.33 \%)$ had all eight positive tumour biopsies.

Clinically, prior to radical prostatectomy, two patients $(2.30 \%)$ met stage T1b, i.e. tumour histological findings in more than $5 \%$ of resected tissue, and the remaining 84 patients had stage T1c $(97.30 \%)$. None of the patients had local or distant metastases.

It was found that there was a statistically significant difference between the preoperative prognostic groups (Table 2) and preoperative tumour-positive biopsy samples ( $p=$ $0.01)$, Gleason value $(p<0.05)$, the second PSA value $(p=$ 0.02 ) and between the postoperative prognostic groups and postoperative tumour stage.

The analysis of histopathological data after radical prostatectomy showed that 20 patients $(23.5 \%)$ had tumour extracapsular involvement (Table 3 ). Only one patient had locoregional metastasis.

There was a significant difference between the postoperative histological stage of the tumour and the total value of the preoperative Gleason score $(p<0.05)$, the total value of the postoperative Gleason score $(p<0.05)$ and prognostic Grade groups before and after prostatectomy $(p<0.05)$.

The mean PSADT was 51 months (7.80-311.81). The mean PSAV was $2.66 \mathrm{ng} / \mathrm{ml} /$ year $(0.22-74.66)$.

PSADT was classified at the following time intervals (see Table 4).

There was a significant correlation between PSADT groups and the preoperative Gleason value and the postoperative Gleason value $(\mathrm{r}=-0.02 ; p 0.05 ; \mathrm{r}=0.08 ; p=0.02)$.

PSAV was determined at the time intervals shown in Table 5. A PSAV value of $2 \mathrm{ng} / \mathrm{ml} /$ year was considered as a cutoff in our study. There were significant differences between the PSAV value and second PSA $(p=0.02 ; \mathrm{r}=0.19)$ and third PSA $(r=0.09 ; p=0.02)$.

Significant correlations were observed between patient tumour risk groups, between second and third PSA values, before and after RP Gleason values, prostate size in grams, PSADT in months, and PSAV (Table 6).

Significant correlation between the first value of PSA and the third value of PSA $(r=0.43 ; p=0.02)$, the second value of PSA ( $r=0.63 ; p<0.05)$, and the size of the prostate was revealed $(\mathrm{r}=0.56 ; p=0.01)$.
Table 1. Patient characteristics

\begin{tabular}{lc}
\hline \multicolumn{1}{c|}{ Characteristics } & Value \\
\hline Age, years & $63(50-75)$ \\
First PSA value, $\mathrm{ng} / \mathrm{ml}$ & $4.29(1.28-13.56)$ \\
Second PSA value, $\mathrm{ng} / \mathrm{ml}$ & $7.76(7.60-47.60)$ \\
Third PSA value, $\mathrm{ng} / \mathrm{ml}$ & $9.67(2.56-98.50)$ \\
PSADT, months & $51.01(7.80-311.81)$ \\
PSAV, ng/ml/per year & $2.66(0.22-74.66)$
\end{tabular}

Table 2. The staging of enrolled patients according to preoperative prognostic groups

\begin{tabular}{|c|c|}
\hline Preoperative prognostic group & Patients, n (\%) \\
\hline 1 & $49(57.0)$ \\
\hline $2 \mathrm{a}$ & $31(36.0)$ \\
\hline $2 b$ & $5(5.8)$ \\
\hline 4 & $1(1.2)$ \\
\hline Total & $86(100.0)$ \\
\hline
\end{tabular}

Table 3. Postoperative staging of patients

\begin{tabular}{lc}
\hline \multicolumn{1}{c}{ Staging (TNM Classification) } & Patients, $\mathrm{n}(\%)$ \\
\hline $2 \mathrm{a}$ & $12(13.9)$ \\
$2 \mathrm{~b}$ & $1(1.6)$ \\
$2 \mathrm{c}$ & $53(61.5)$ \\
$3 \mathrm{a}$ & $11(12.6)$ \\
$3 \mathrm{~b}$ & $9(10.4)$
\end{tabular}

Table 4. The subdivision of patients according to different PSADT time intervals

\begin{tabular}{lc}
\hline \multicolumn{1}{c}{ PSADT intervals in months } & Patients, $\mathrm{n}(\%)$ \\
\hline $0-12$ & $10(11.6)$ \\
$12-24$ & $16(18.6)$ \\
$24-48$ & $24(27.9)$ \\
$>48$ & $36(41.9)$ \\
Together & $86(100.0)$
\end{tabular}

Table 5. The subdivision of patients according to different PSAV values

\begin{tabular}{|c|c|}
\hline PSAV classification $\mathrm{ng} / \mathrm{ml} /$ year & Patients, n (\%) \\
\hline$<2$ & $56(65.1)$ \\
\hline$>2$ & $30(34.9)$ \\
\hline Together & $86(100.0)$ \\
\hline
\end{tabular}

Table 6. Correlation between patient tumour risk groups and clinical, histopathological characteristics, PSAV and PSADT value (Spearman test)"

\begin{tabular}{lccc}
\hline \multicolumn{1}{c}{ Values } & $\mathrm{r}$ & $p$ \\
\hline Age, years & -0.09 & 0.936 \\
First PSA, ng/ml & 0.12 & 0.890 \\
Second PSA, ng/ml & 0.21 & 0.019 \\
Third PSA, ng/ml & 0.15 & 0.022 \\
Positive biopsies & 0.24 & 0.392 \\
Pre-RP Gleason score & 0.33 & $<0.05$ \\
Post-RP Gleason score & 0.29 & 0.04 \\
Prostate volume & 0.09 & $<0.05$ \\
PSADT, month & 0.01 & $<0.05$ \\
PSAV, ng/ml/year & 0.32 & $<0.05$
\end{tabular}


There was a significant correlation between the second PSA value and the pre- RP Gleason value $(\mathrm{r}=0.23 ; p=0.04)$ and preoperative positive tumour biopsies $(\mathrm{r}=0.21 ; p=$ $0.04)$.

There was a significant correlation between the third PSA value and the first PSA value $(\mathrm{r}=0.43 ; p=0.02)$, the second PSA value $(\mathrm{r}=0.90 ; p<0.05)$, the Gleason value before RP $(\mathrm{r}=0.22 ; p=0.04)$, and PSAV $\mathrm{ng} / \mathrm{ml} /$ year $(\mathrm{r}=0.33$; $p=0.02)$.

There was a significant correlation between PSADT in months and the second value of PSA $(\mathrm{r}=0.31 ; p<0.05)$, PSAV $(\mathrm{r}=-0.78 ; p 0.05)$, prostate size $(\mathrm{r}=0.26 ; p=0.01)$, PSADT classification groups in months $(\mathrm{r}=0.95 ; p<0.05)$, PSAV $2 \mathrm{ng} / \mathrm{ml} /$ year classification groups $(\mathrm{r}=-0.67 ; p<$ $0.05)$.

There was a significant correlation between PSAV $\mathrm{ng} / \mathrm{ml} /$ year and the third value of PSA $(\mathrm{r}=0.33 ; p 0.05)$, the second value of PSA $(r=0.28 ; p<0.05)$ (Fig. 1$)$, the postoperative Gleason value $(\mathrm{r}=0.44 ; p<0.05)$, tumourpositive biopsies $(\mathrm{r}=0.32 ; p 0.05)$, patient risk groups $(\mathrm{r}=$ $0.32 ; p<0.05)$, PSADT classification groups per month $(\mathrm{r}=$ $-0.73 ; p<0.05)$, and PSAV $2 \mathrm{ng} / \mathrm{ml} /$ year classification groups $(\mathrm{r}=0.83 ; p<0.05)$.

A significant correlation was found between the PSADT classification groups in months, the second value of PSA $(\mathrm{r}=0.29 ; p<0.05)$, PSADT $(\mathrm{r}=-0.781 ; p<0.05)$, PSAV $(\mathrm{r}=0.73 ; p<0.05)$, and prostate size $(\mathrm{r}=0.23 ; p=0.03)$.

\section{DISCUSSION}

Since the introduction of widespread PSA-based prostate cancer monitoring, several markers have been employed to aid in detection of prostate cancer. The change in PSA level over time, PSAV, is such a marker that may improve specificity; however, its role as an adjunct to PSA is controversial (Epstein et al., 2005; Billis et al., 2008; Eggener et al., 2008; Loeb et al., 2010; Loeb et al., 2012).

The prognostic value of primary PSA kinetics in prostate cancer patients subjected to radical prostatectomy has been discussed in several works. However, the clinical significance of PSAV and PSADT with clinical and histopathological characteristics before and after radical prostatectomy has been compared only in a few studies.

Some previous studies demonstrated that PSAV provides independent predictive information for estimating prostate cancer risk and a PSAV threshold of 0.35 to $0.4 \mathrm{ng} / \mathrm{ml} /$ year has been associated with the likelihood of prostate cancer, suggesting that PSAV might have a significant role in stratification of patients for prostate cancer (Eggener et al., 2008; Loeb et al., 2010; Loeb et al., 2012).

In contrast, some studies have shown that PSAV has limited value, and taking biopsies for men with high PSAV, but no

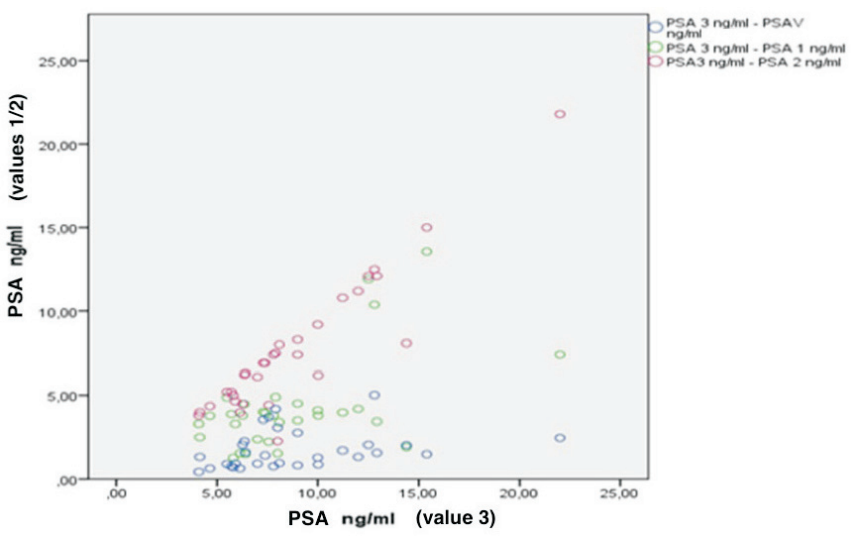

Fig. 1. Correlation between first, second, third PSA values and PSAV; Spearman test. Rho $=0.329 ; p=0.02$.

other indication, would lead to a large number of additional prostate biopsies (Vickers et al., 2009).

Our study demonstrated significant correlation between PSAV and the third PSA, second PSA value, postoperative Gleason score and the numbers of positive tumour biopsy samples.

Our findings supported previous evidence of a literature review and extend it (Rana et al., 1992; Lorente et al., 1996; D'Amico et al., 2004; Khatami et al., 2007).

It was demonstrated that patients with PSAV $>2 \mathrm{ng} / \mathrm{ml} /$ year one year before a diagnosis of PCa had a 9.8-fold increased risk of dying from PCa after RP, compared to men with PSAV $<2$ ng/ml/year (Rana et al., 1992).

According to previous studies, the mean PSAV in high-risk patients was 2.1, and in low-risk patients $0.07 \mathrm{ng} / \mathrm{ml} /$ year (Loeb et al., 2008). In our study, in high-risk patients the level of PSAV was fivefold more $(10.94 \mathrm{ng} / \mathrm{ml} / \mathrm{year})$ than in low-risk patients $(1.81 \mathrm{ng} / \mathrm{ml} /$ year $)$, and the mean first PSA value in high-risk PCa patients was $16.5 \mathrm{ng} / \mathrm{ml}$.

The differences between the PSAV value in our study and and previous work (Loeb et al., 2008) can be explained by different observation time periods and subject characteristics, since in our study only a small proportion of patients were stratified as high risk before the radical prostatectomy.

The importance of standardising PSA values was demonstrated in previous studies, in which the prognostic role of PSAV for biochemical tumour recurrence and the development of metastases was not demonstrated in the same group of patients based on PSAV values taken one year before RP, despite interval differences between individual PSA values (D'Amico et al., 2004). However, the predictive role of PSAV for biochemical recurrence and metastasis was demonstrated using PSAV values determined using a six months minimum time interval between individual PSA values in the same one-year period (Eggener et al., 2008; Vickers et al., 2009). 
In addition, our study revealed correlation between PSA value and prostate size, which was consistent with previous findings (Schmid et al., 1993).

Our data are consistent with previous findings that demonstrated strong correlation between tumour size and PSA, a constant logarithmic-linear positive growth rate of prostate tumour, and strong correlation between the preoperative biopsy Gleason number and PSA value (Schmid et al., 1993).

Furthermore, in our study the third PSA value before RP was correlated with the Gleason value before RP. In addition, the second PSA value was correlated with the preoperative Gleason score and the number of positive tumour core biopsies.

It has been suggested that the likelihood of developing lymph node metastases and extracapsular tumour growth begins to increase only in tumours larger than $4 \mathrm{ml}^{2}$, while in the general population about $80 \%$ of prostate tumours are less than $0.5 \mathrm{ml}^{2}$ without symptoms and without being detected, and most patients would need approximately 12 years for a $0.5 \mathrm{ml}^{2}$ tumour to reach $4 \mathrm{ml}^{2}$ if their PSA doubling time were 48 months (Schmid et al., 1993).

It should be stressed that transrectal ultrasound (TRUS) can detect prostate tumours up to $0.2 \mathrm{ml}^{2}$, but biopsies can identify even smaller tumors; by calculating the time of PSA doubling, it would be easy to determine the course of development and the need for further treatment of the prostate tumour and avoid "over" diagnosis and incorrect treatment (Schmid et al., 1993).

PSADT has been suggested to be sensitive to exponential tumour growth and progression (Choo et al., 2004).

The hypothesis that more than one PSA value over time would allow the dynamics of tumour development to be assessed dynamically and provide diagnostic and therapeutic solutions for patients with prostate cancer, especially for those with a high relative risk $(26.9 \%)$ of developing PCa at low PSA values (3.1-4.0 ng/ml) (Thompson et al., 2004) prompted the calculation and evaluation of PSADT.

PSADT was defined as a value that measures the increase in serum PSA per unit time, reflecting its relative variability (Schmid et al., 1993). Post-treatment PSADT was primarily used to determine the biochemical recurrence survival of men with PCa, but information on the use of PSADT in predicting pre-treatment biological development of the tumour, especially in its early stages, is rather limited (Lorente et al., 1996).

In our study significant differences were observed between PSADT and the second value of PSA, prostate size and pre-and postoperative Gleason score, which is in line with previous findings (Schmid et al., 1993; Arlen et al., 2008; Heidenreich, 2008; Ramirez et al., 2008).

It has been previously demonstrated that the role of PSADT is limited by fluctuations in PSA values, depending on the time interval between individual PSA (Ramirez et al., 2008).

It has been reported that the minimum time interval between individual pre-treatment PSA values was 12 months (Schmid et al., 1993). In contrast, some other studies suggested that the minimum time interval between first and last pre-treatment PSA values was five years (Loeb et al., 2010).

Other studies reported that the minimum interval between individual PSA values was from 6 to 12 months (O'Brien et al., 2009; Schröder et al., 2009).

Therefore, the definition of the time interval between individual PSA measurement is of particular importance. A 12month time interval seems beneficial and effective.

Studies to elucidate the correlation between pre-treatment PSADT and histopathological tumour stage (including Gleason number, extracapsular tumor growth, resection lines) have yielded different, contradictory results and incorporation of pre-treatment PSADT in determining the current clinical stage does not increase the accuracy of tumour prognostic models (Ramirez et al., 2008).

It is recommended that the patient's last pre-treatment PSA be used alone or in combination with the clinical stage and histological gradation of the tumour to make further treatment decisions (O’Brien et al., 2009).

Some previous studies suggested that PSADT and PSAV have a limited diagnostic role in the identification of $\mathrm{PCa}$ due to a different background history (total prostate volume, $\mathrm{BPH})$ at intervals ranging from PSA detection. These measurements do not provide additional information compared to the information provided by PSA alone (Moul et al., 2004; Mottet et al., 2020).

Our study revealed a significant correlation between the PSADT and PSAV classification groups and prostate size, and pre- and postoperative Gleason grading. These findings are in line with previous reports about the value of PSADT and PSAV in prostate cancer prognosis (D'Amico and Hanks, 1993; Lorente et al., 1996; McLaren et al., 1998; Stephenson et al., 2002; Raaijmakers et al., 2004; Stewart et al., 2005; Sengupta et al., 2006; Oudard et al., 2007; Spurgeon et al., 2007; Vickers et al., 2009). In addition to previously published data, the results of our study extended previous findings demonstrated correlation between PSAV, PSADT and clinicopathological characteristics in the same patients before and after radical prostatectomy.

\section{CONCLUSIONS}

This study demonstrated that PSAV and PSADT were significantly correlated with preoperative tumour biopsy specimens, postoperative Gleason score and prognostic patients' risk groups, demonstrating and confirming its role in the di- 
agnosis of prostate cancer and of determination its progression.

Our study is in line with previous studies in the field, but is representive of the Latvian population that is completely different from that in the USA. As far as we know, no such studies have been conducted in Latvia. The fact that we can reproduce results of studies performed in different populations provides additional validation of results of studies by other authors, affirming previously observed results.

\section{CONFLICT OF INTEREST}

The authors declare no conflicts of interest.

\section{REFERENCES}

Arlen, P. M., Bianco, F., Dahut, W. L. (2008). Specific Antigen Working Group guidelines on prostate specific antigen doubling time. J. Urol., 179 (6), 2181-2185; discussion 2185-2186

Bartsch, G., Horninger, W., Klocker, H. (2001). Prostate cancer mortality after introduction of prostate specific antigen mass screening in the Federal State of Tyrol, Austria. Urology, 58 (3), 417-424.

Billis, A., Guimaraes, M. S., Freitas, L. L. (2008). The impact of the 2005 International Society of Urological Pathology consensus conference on standard Gleason grading of prostatic carcinoma in needle biop-sies. J. Urol., 180 (2), 548-5452; discussion 552-553.

Carter, H. B., Pearson, J. D., Metter, E. J. (1992). Longitudinal evaluation of prostate-specific antigen levels in men with and without prostate disease. JAMA, 267 (16), 2215-2220.

Choo, R., Klotz, L., Deboer, G., Danjoux, C., Morton, G. (2004). Wide variation of prostate-specific antigen doubling time of untreated, clinically localized, low-to-intermediate grade, prostate carcinoma. Brit. J. Urol. Int., 94 (3), 295-298.

D’Amico, A. V., Hanks, G. E. (1993). Linear regressive analysis using prostate-specific antigen doubling time for predicting tumor biology and clinical outcome in prostate cancer. Cancer, 72 (9), 2638-2643.

D'Amico, A. V., Chen, M. H., Roehl, K. A., Catalona, W. J. (2004). Preoperative PSA velocity and the risk of death from prostate cancer after radical prostatectomy. New Engl. J. Med., 351 (2), 125-135.

Eggener, S. E., Yossepowitch, O., Roehl, K. A. (2008). Relationship of prostate-specific antigen velocity to histologic findings in a prostate cancer screening program. Urology, 71 (6), 1016-1019.

Epstein, J. I., Allsbrook, W. C. J., Amin, M. B. (2005). ISUP grading committee. The 2005 International Society of Urologic Pathology (ISUP) Consensus Conference on Gleason grading of Prostatic Carcino-ma. Amer. J. Surg. Pathol., 29 (9), 1228-1242.

Folkmanis, K., Eglitis, J., Jakubovskis, M., Lietuvietis, V., Folkmane, I, Isajevs, S. CD63 and DNA mismatch repair protein expression in prostate cancer. Proc. Latvian Acad. Sci., Section B, 75 (3), 180-185.

Heidenreich, A. (2008). Identification of high-risk prostate cancer: Role of prostate-specific antigen, PSA doubling time, and PSA velocity. Eur. Urol., 54 (5), 976-977; discussion 978-979.

Ilic, D., O'Connor, D., Green, S. (2007). Screening for prostate cancer: A Cochrane systematic review. Cancer Causes Control., 18 (3), 279-285.

Khatami, A., Aus, G., Damber, J. E., Lilja, H., Lodding, P., Hugosson, J. (2007). PSA doubling time predicts the outcome after active surveillance in screening-detected prostate cancer: Results from the European randomized study of screening for prostate cancer, Sweden section. Int. J. Cancer, 120 (1), 170-174.

Loeb, S., Kettermann, A., Ferrucci, L., Landis, P., Metter, E. J., Carter, H. B. (2008). PSA doubling time versus PSA velocity to predict high-risk pros- tate cancer: Data from the Baltimore Longitudinal Study of Aging. Eur. Urol., 54 (5), 1073-1080.

Loeb, S., Metter, E. J., Kac, D. (2012). Prostate-specific antigen velocity (PSAV) risk count improves the specificity of screening for clinically significant prostate cancer. Brit. J. Urol. Int., 109 (4), 508-513.

Loeb, S., Roehl, K. A., Helfand, B. T. (2010). Can prostate specific antigen velocity decrease insignificant prostate cancer detection? J. Urol., 183 (1), $112-116$.

Lorente, J. A., Morote, J., Raventos, C. (1996). Clinical efficacy of bone alkaline phosphatase and prostate specific antigen in the diagnosis of bone metastasis in prostate cancer. J. Urol., 155 (4), 1348-1351.

Lu-Yao, G., Albertsen, P. C., Stamford, J. L. (2002). Natural experiment examining impact of aggressive screening and treatment on prostate cancer mortality in two fixed cohorts from Seattle area and Con-necticut. Brit. Med. J., 325 (7367), 740.

McLaren, D. B., McKenzie, M., Duncan, G., Pickles, T. (1998). Watchful waiting or watchful progression? Prostate specific antigen doubling times and clinical behavior in patients with early untreated prostate carcinoma. Cancer, 82 (2), 342-348.

Mottet, N., Cornford, P., van den Bergh, R. C. N., De Santis, M., Fanti, S., Gillessen, S., Grummet, J., Henry, A.M., Lam, T. B., Mason, M. D., van der Kwast, T. H. et al. (2020). Oncology Guidelines, Prostate Cancer. https://uroweb.org/guideline/prostate-cancer/ (accessed 14.07.2021).

Moul, J. W., Wu, H., Sun, L. (2004). Early versus delayed hormonal therapy for prostate specific antigen only recurrence of prostate cancer after radical prostatectomy. J. Urol., 171 (3), 1141-1147.

O'Brien, M. F., Cronin, A. M., Fearn, P. A. (2009). Pretreatment prostate-specific antigen (PSA) velocity and doubling time are associated with outcome but neither improves prediction of outcome beyond pre-treatment PSA alone in patients treated with radical prostatectomy. J. Clin. Oncol., 27 (22), 3591-3597.

Oudard, S., Banu, E., Scotte, F. (2007). Prostate-specific antigen doubling time before onset of chemotherapy as a predictor of survival for hormone-refractory prostate cancer patients. Ann. Oncol., 18 (11), 1828-1833.

Post, P. N., Kil, P.J., Coebergh, J. W. (1999). Trends in survival of prostate cancer in southeastern Netherlands 1971-1989. Int. J. Cancer, 81 (4), 551-554.

Pound, C. R., Partin, A. W., Eisenberger, M. A., Chan, D. W., Pearson, J. D., Walsh, P. C. (1999). Natural history of progression after PSA elevation following radical prostatectomy. JAMA, 281 (17), 1591-1597.

Pruthi, R. S., Johnstone, I., Tu, I. P., Stamey, T. A. (1997). Prostate-specific antigen doubling times in patients who have failed radical prostatectomy: correlation with histologic characteristics of the primary cancer. Urology, 49 (5), 737-742.

Raaijmakers, R., Wildhagen, M. F., Ito, K. (2004). Prostate-specific antigen change in the European Randomized Study of Screening for Prostate Cancer, section Rotterdam. Urology, 63 (2), 316-320.

Ramirez, M. L., Nelson, E. C., Devere White, R. W. (2008). Current applications for prostate-specific antigen doubling time. Eur. Urol., 54 (2), 291-300.

Rana, A., Karamanis, K., Lucas, M. G. (1992). Identification of metastatic disease by $\mathrm{T}$ category, Gleason score and serum PSA level in patients with carcinoma of the prostate. Brit. J. Urol., 69 (3), 277-281.

Ross, P. L., Mahmud, S., Stephenson, A. J., Souhami, L., Tanguay, S., Aprikian, A. G. (2004). Variations in PSA doubling time in patients with prostate cancer on "watchful waiting": value of short-term PSADT determinations. Urology, 64 (2), 323-328.

Schmid, H. P., McNeal, J. E., Stamey, T. A. (1993). Observations on the doubling time of prostate cancer. The use of serial prostate-specific antigen in patients with untreated disease as a measure of increasing cancer volume. Cancer, 71 (6), 2031-2040.

Schröder, F. H., Hugosson, J., Roobol, M. J. (2009). ERSPC Investigators. Screening and prostate-cancer mortality in a randomized European study. New Engl. J. Med., 360 (13), 1320. 
Sengupta, S., Blute, M. L., Bagniewski, S. M. (2006). Increasing prostate specific antigen following radical prostatectomy and adjuvant hormonal therapy: Doubling time predicts survival. J. Urol., 175 (5),1684-1690.

Spurgeon, S. E., Mongoue-Tchokote, S., Collins, L. (2007). Assessment of prostate-specific antigen doubling time in prediction of prostate cancer on needle biopsy. Urology, 69 (5), 931-935.

Stephenson, A. J., Aprikian, A. G., Souhami, L., Behlouli, H., Jacobson, A. I., Bégin, L. R., Tanguay, S. (2002). Utility of PSA doubling time in fol- low-up of untreated patients with localized prostate cancer. Urology, $\mathbf{5 9}$ (5), 652-656.

Stewart, A. J., Scher, H. I., Chen, M. H. (2005). Prostate-specific antigen nadir and cancer-specific mortality following hormonal therapy for prostate-specific antigen failure. J. Clin. Oncol., 23 (27), 6556-6560.

Thompson, I. M., Pauler, D. K., Goodman, P. J. (2004). Prevalence of prostate cancer among men with a prostate-specific antigen level $<$ or $=4.0 \mathrm{ng}$ per milliliter. New Engl. J. Med., 350 (22), 2239-2246.

Vickers, A. J., Savage, C., O’Brien, M. F. (2009). Systematic review of pretreatment prostate-specific antigen velocity and doubling time as predictors for prostate cancer. J. Clin. Oncol., 27 (3), 398-403.

Received 7 June 2021

Accepted in the final form 14 July 2021

\section{PROSTATAS SPECIFISKĀ ANTIGĒNA DINAMIKA UN İPATNĪBAS PACIENTIEM AR PROSTATAS AUDZĒJU}

Neraugoties uz prostatas specifiskā antigēna (PSA) seruma līmeni, ko parasti izmanto kā audzēja markiieri prostatas audzēja diagnostikā, varētu uzskatīt, ka PSA dubultošanās laiks (PSADT) un PSA ātrums (PSAV) varētu būt noderīgāks audzēja attīstības un prognozes rādītājs pacientiem ar prostatas audzēju nekā PSA rādītājs atsevišḳi. Pētījuma mērkis bija novērtēt PSAV un PSADT vērtības prostatas audzēja diagnostikā un to saistību ar prostatas audzēja histopatoloǵiskajām īpašībām. Pētījumā bija iekḷauti astoṇdesmit seši pacienti, kuriem tika veikta radikāla prostatektomija. Pamatojoties uz PSA mērījumiem, tika aprēkināâtas PSA dinamiskās vērtības: PSADT un PSAV. Turklāt tika novērtētas klīniskās un histopatoloğiskās īpašības, ieskaitot slimības stadiju un prognostiskās grupas. Iegūtie rezultāti parādīja, ka pirmā vidējā PSA vērtība pacientiem bija 4,29 ng/ml (1,28-13,56), otrā PSA vērtība bija 7,76 ng/ml (7,60-47,60), bet trešā PSA vērtība bija 9,67 ng/ml (2,56-88,50). Vidējais PSADT bija 51,01 mēneši (7,80-311,81), vidējais PSAV bija 2,66 ng/ml gadā $(0,22-4,66)$. Turklāt tika novērotas korelācijas starp PSAV un pirms un pēcoperācijas Gleason rādītājiem, kā arī prognostiskajām grupām. Tika parādīta korelācija starp PSADT un pirms un pēcoperācijas Gleason rādītājiem un prognostiskā riska grupām. Pētījums parādīja, ka PSAV un PSADT korelēja ar pēcoperācijas Gleason rādītāju un prognostiskā riska grupām, parādot tā lomu prostatas audzēja attīstības dinamikas diagnostikā. 